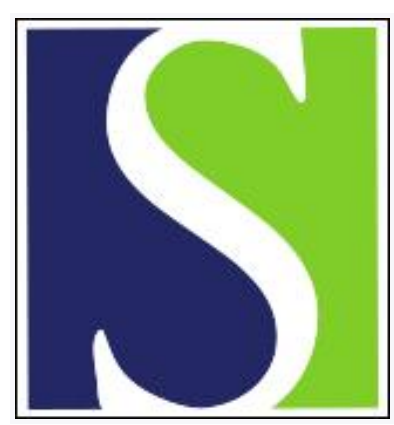

Scand J Work Environ Health 1987;13(4):363-366

https://doi.org/10.5271/sjweh.2043

Issue date: Aug 1987

Pathogenic and clinical aspects of polyneuropathies, with reference to the hand-arm vibration syndrome.

by Juntunen J, Taskinen $\mathrm{H}$

Affiliation: Department of Occupational Medicine, Institute of Occupational Health, Helsinki, Finland.

This article in PubMed: www.ncbi.nlm.nih.gov/pubmed/3324315

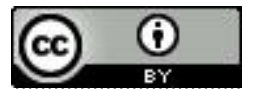




\title{
Pathogenic and clinical aspects of polyneuropathies, with reference to the hand-arm vibration syndrome
}

\author{
by Juhani Juntunen, MD, Helena Taskinen, MD ${ }^{1}$
}

\begin{abstract}
JUNTUNEN J, TASKINEN H. Pathogenic and clinical aspects of polyneuropathies, with reference to the hand-arm vibration syndrome. Scand J Work Environ Health 13 (1987) 363-366. Along with attacks of white finger, symptoms suggesting peripheral sensorimotor neuropathy, ie, polyneuropathy or entrapment neuropathy, are very important in the hand-arm vibration syndrome. Peripheral neuropathies are probably associated with the occurrence of the syndrome because of a selection mechanism. Polyneuropathy may be a contributing factor in the development of entrapment neuropathies in the upper extremities. It has multiple pathogenic mechanisms and numerous causative factors. However, peripheral nerves can react to pathological stimuli in a limited number of ways. Wallerian degeneration, segmental demyelination, and axonal degeneration are the classical neuropathological types of peripheral neuropathies, of which the first two are possible direct consequences of vibration exposure. The clinical manifestations of polyneuropathy range from sensory to motor types, sometimes with autonomic involvement. Whenever polyneuropathy is encountered in the hand-arm vibration syndrome, its etiologic possibilities should be considered. Regardless of the variable criteria used by different authors, individual diagnosis of the syndrome is always a probability diagnosis, and adequate neurological differential diagnostics have to be employed.
\end{abstract}

Key terms: diagnosis, pathogenesis, vibration syndrome.

\begin{abstract}
Among the multiple symptoms and signs of the handarm vibration syndrome, those due to disturbance in the function of the nervous system and white-finger attacks are the most important. Paresthesias, numbness, muscular weakness, and atrophy may be signs of sensorimotor peripheral neuropathy. Most clinical studies on the syndrome have primarily emphasized structures and functions of the upper extremities. Regardless of the variable diagnostic criteria used by different authors for the hand-arm vibration syndrome, entrapment neuropathies of the upper extremities, notably the carpal tunnel syndrome, comprise an important differential diagnostic problem, as discussed by, eg, Dawson et al (1). It is also obvious that more proximal nerve entrapments may confuse the clinical picture (9). Moreover, patients with more generalized peripheral neuropathy or weakness of the peripheral nerves tend to be diagnosed more easily as having the syndrome (8). In neurological examinations of these patients, other possible etiologies of neurological disturbances have to be carefully excluded. Some general aspects of polyneuropathy, which is very important when the hand-arm vibration syndrome is being considered, are discussed in this paper.
\end{abstract}

\section{Polyneuropathy}

Polyneuropathy refers to a diffuse symmetric involvement of the peripheral nervous system, and it may

1 Institute of Occupational Health, Helsinki, Finland.

Reprint requests to: Dr J Juntunen, Department of Occupational Medicine, Institute of Occupational Health, Topeliuksenkatu 41 a A, SF-00250 Helsinki, Finland. occur in many diseases. Polyneuropathies are classified into the following four broad categories according to their etiology: nutritional polyneuropathy, metabolic polyneuropathy, toxic polyneuropathy, and polyneuropathy due to drugs (table 1).

In spite of the heterogeneity of the pathogenic mechanisms of peripheral neuropathies [see for instance, Dyck et al (2)] the peripheral nerve reacts only in a limited number of ways to pathological stimuli. From the neuropathological point of view, peripheral neuropathies can be classified into those following mechanical trauma (Wallerian degeneration), those due to primary involvement of the axon (axonal neuropathies), and those with primary involvement of the Schwann cells (segmental demyelination). For further details, see figure 1 . In the hand-arm vibration syndrome the two possible neuropathological mechanisms are classical Wallerian degeneration through direct trauma caused by vibration and segmental demyelination through ischemic damage to the nerve from vasospasms.

\section{Clinical picture}

The clinical manifestations of polyneuropathies range from pure sensory to sensorimotor or motor types. Autonomic polyneuropathy is also often present, although seldom without simultaneous sensorimotor polyneuropathy (7). In practice, acute, subacute, and chronic types of polyneuropathy can be distinguished. The progressive sensory disturbances of the stockingglove distribution, together with distal muscular weakness and diminished or absent muscle tendon reflexes, should be examined in each individual presenting symptoms typical for polyneuropathy. The symptoms 
Table 1. Deficiency states, diseases, chemicals, and drugs associated with the occurrence of polyneuropathy [from Juntunen (6)].

\begin{tabular}{|c|c|c|c|}
\hline $\begin{array}{l}\text { Dietary } \\
\text { deficiencies }\end{array}$ & $\begin{array}{l}\text { Metabolic and } \\
\text { other diseases }\end{array}$ & Chemicals & Drugs \\
\hline $\begin{array}{l}\text { Thiamine (B1) } \\
\text { Pyridoxine (B6) } \\
\text { Pantothenic acid } \\
\text { Riboflavine } \\
\text { Folic acid } \\
\text { Niacin }\end{array}$ & $\begin{array}{l}\text { Diabetes } \\
\text { Cancer } \\
\text { Rheumatic diseases } \\
\text { Amyloidoses } \\
\text { Disturbances in } \\
\text { lipid metabolism } \\
\text { Hypoglycemia } \\
\text { Hypothyreosis } \\
\text { Sarcoidosis } \\
\text { Porphyria } \\
\text { Idiopathic diseases } \\
\text { Polyneuropathy } \\
\text { Uremia } \\
\text { Hepatic diseases } \\
\text { Leprosy } \\
\text { Obstructive lung } \\
\text { diseases } \\
\text { Tangier's disease } \\
\text { Macroglobulinemias }\end{array}$ & $\begin{array}{l}\text { Acrylamide } \\
\text { Tri-orthocresyl-phosphate } \\
\text { Arsene } \\
\text { Mercury } \\
\text { Lead } \\
\text { Benzene } \\
\text { Toluene } \\
\text { Xylene } \\
\text { Styrene } \\
n \text {-Hexane } \\
\text { Alcohol } \\
\text { Methyl-n-butyl-ketone } \\
\text { Tri- and tetrachloroethylene } \\
\text { Carbon disulfide } \\
\text { Manganese } \\
\text { Thallium } \\
\text { Nitrous oxide } \\
\text { Allyl chloride }\end{array}$ & $\begin{array}{l}\text { Nitrofurantoin } \\
\text { Chloramphenicol } \\
\text { Chloroquine } \\
\text { Isoniazine } \\
\text { Diphenylhydantoin } \\
\text { Indomethacin } \\
\text { Hydralazine } \\
\text { Gold } \\
\text { Levodopa } \\
\text { Methaqualone } \\
\text { Vincristine } \\
\text { Disulphiram } \\
\text { Ergotamine } \\
\text { Cisplatin } \\
\text { Hydroxyquinoline } \\
\text { Misonidazole } \\
\text { Perhexiline }\end{array}$ \\
\hline
\end{tabular}
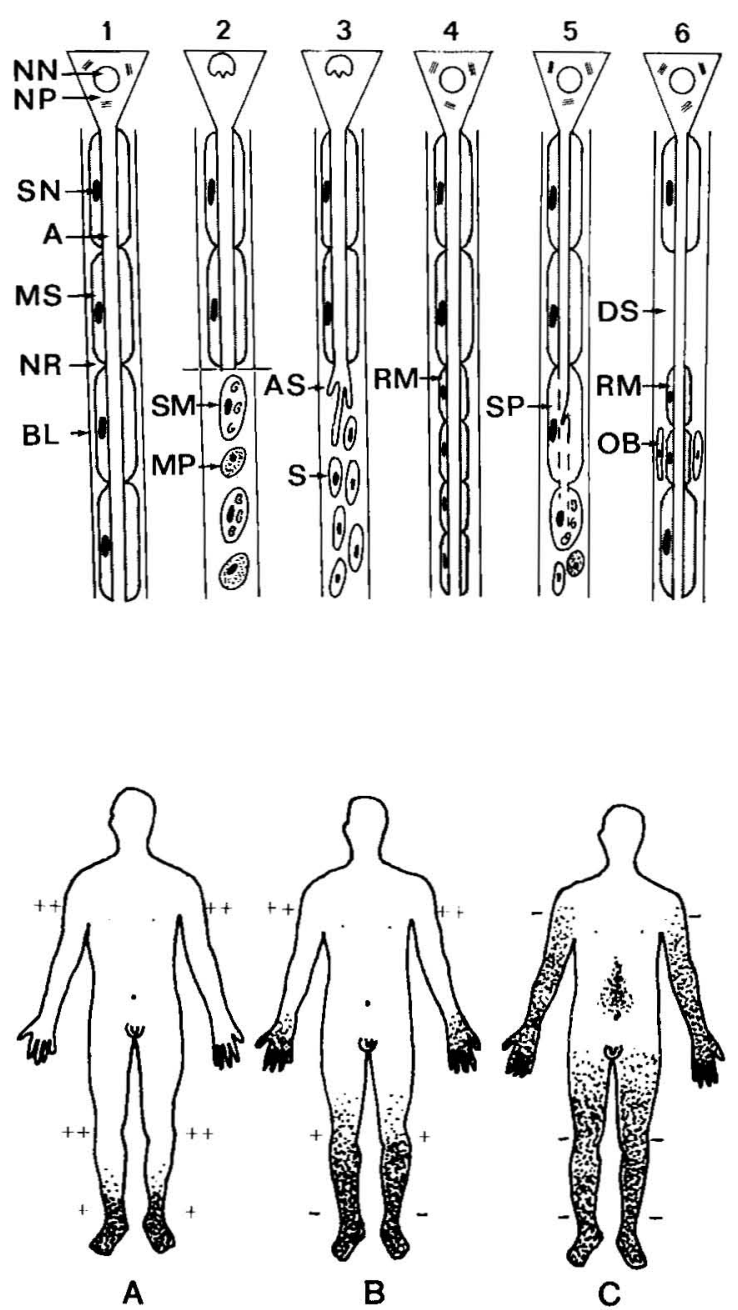

Figure 2. Progression of sensory disturbances and reflex loss in polyneuropathy (Reproduced with permission from Juntunen \& Kemppainen, Duodecim 98, 1982).
Figure 1. Basic reaction patterns of a peripheral myelinated axon in pathological conditions. (Reproduced with permission from Juntunen \& Haltia. Acta Neurol Scand, suppl 92, vol 66, 1982). $(1=$ normal structural components of a peripheral mye linated axon; $2=$ Wallerian degeneration; $3=$ axonal sprouting $4=$ regeneration and remyelination of the axon; $5=$ axonal degeneration of dying-back neuropathy; $6=$ segmental demyelination, remyelination, and onion bulb formation; $\mathrm{NN}=$ neu ronal nucleus; $\mathrm{NP}=$ neuronal perikaryon; $\mathrm{SN}=\mathrm{Sch}$ wann cell nucleus; $A=$ axon; $M S=$ myelin sheath; $N R=$ node of Ranvier $\mathrm{BL}=$ basal lamina; $\mathrm{SM}=\mathrm{Sch}$ wann cell with myelin debris $\mathrm{MP}=$ macrophage; $\mathrm{AS}=$ axonal sprout $\mathbf{S}=$ proliferating Schwann cells; RM = remyelinated myelin segment; $S P=S c h w a n n$ cel sequestering and phagocytizing disintegrated axonal material; $\mathrm{DS}=$ demyelinated segment with denuded axon; $\mathrm{OB}=$ concen tric Schwann cell processes forming an "onion bulb")

are usually burning feet or other sensory disturbances which occur symmetrically and the degree of which usually increases at night.

The spatial distribution of typical sensory deficits in various stages of polyneuropathy is shown in figure 2. Sensory deficit extends above the knee before the hand is affected (figure 2 B). When the deficit extends to the proximal parts of the extremities, a typical sensory defect, the tear-drop defect, is present over the abdomen (figure $2 \mathrm{C}$ ). In contrast to the border of hysteric sensory deficits, the border between normally and abnormally sensitive skin is not sharp. Diminished muscle tendon reflexes are usually first observed in the gastrocnemius muscles and thereafter in more proximal muscles.

The characteristic development of the signs of polyneuropathy is due to loss of function of the nerves according to their length, regardless of the underlying neuropathological mechanism. 


\section{Diagnostic criteria for polyneuropathy}

The diagnostic criteria for polyneuropathy are the following (7):

1. The patient has subjective symptoms compatible with polyneuropathy.

2. The clinical examination reveals diminished or absent muscle tendon reflexes, muscular atrophy and weakness, and typical sensory deficits.

3. Electroneuromyography shows at least one abnormally slow nerve conduction velocity in both the upper and the lower extremities or two abnormally slow nerve conduction velocities in the lower extremities. Evidence of neurogenic muscle damage is also observed.

If a case fulfills two of these diagnostic criteria, the diagnosis of polyneuropathy can be considered established. The importance of polyneuropathy in the handarm vibration syndrome lies in the fact that diseased or "weak" peripheral nerves, regardless of the etiology, are less resistant to additional exogenous factors such as vibration exposure. The same holds true with regard to entrapment neuropathies, which are often early manifestations of underlying polyneuropathies.

Therefore, patients with mild peripheral neuropathy are likely to be found among those patients with suspected hand-arm vibration syndrome (8). It should be pointed out that knowledge on the epidemiology of polyneuropathies is rather limited. For some types of polyneuropathies, data are available on the prevalence or incidence, but the figures vary greatly. In a normal population, signs suggesting peripheral neuropathy can be detected in less than $5 \%$, depending, of course, on the diagnostic criteria. The prevalence of these findings increases with aging. In a recent field study on forest workers in Finland (3), the prevalence of peripheral neuropathy of the polyneuropathic type was $4 \%$.

\section{Diagnosis of occupationally related hand-arm vibration syndrome in Finland}

The diagnostic criteria for occupationally related handarm vibration syndrome in Finland are the following:

\section{Verified relevant vibration exposure.}

2. Typical clinical picture which includes typical subjective symptoms (attacks of white finger, numbness, paresthesias, loss of dexterity) and objective findings in a clinical examination on peripheral vasospasm and/or neuropathy dominant in the upper extremity.

3. Primary Raynaud's disease, idiopathic Raynaud's syndrome, and peripheral neuropathies of other etiologies reasonably well excluded.
The first requisite for the diagnosis of the hand-arm vibration syndrome is "sufficient" exposure to handarm vibration from a vibrating tool. Among lumberjacks the mean latency for the development of vibration-induced white finger was 5600 workhours, corresponding to four to five years of professional use of chain saws (11). In a special type of pedestal grinding at a foundry, however, the mean latency for white finger symptoms was only 10.3 months (14). The frequency, acceleration, and impulsiveness of the vibration determine the vibration hazard (13).

The typical symptoms of vibration disease are Raynaud's phenomenon, numbness and paresthesias in the hands, and, in advanced cases, muscle fatigue and loss of manual dexterity.

Objective signs of the vasospastic attacks or defects in neurological functions are required for the diagnosis of the syndrome. Various cold provocation tests have been used to verify Raynaud's phenomenon. If Raynaud's phenomenon is detected by inspection only, a negative result does not exclude the possibility of the syndrome (10). With plethysmographic methods, better sensitivity in cold provocation tests has been achieved (10). The role played by the autonomic nervous system in vasospasm is unclear, but interesting inferences have been made on disturbances in autonomic functions (4).

Epidemiologic studies in Finland have shown that the prevalence of the most prominent symptom of the hand-arm vibration syndrome, ie, attacks of white finger, decreased clearly with a decrease in vibration exposure (12). However, numbing symptoms did not correlate with vibration exposure (5). In this respect, the possibility of nerve entrapments (9) or polyneuropathy (8) may explain the continuing symptoms. It is conceivable that the polyneuropathy associated with the hand-arm vibration syndrome is more severe in the upper extremities. In fact, this phenomenon should be one of the diagnostic criteria of the syndrome in cases in which polyneuropathy is encountered.

In conclusion, neurological differential diagnostics of the hand-arm vibration syndrome consists of the exclusion of entrapment neuropathies and polyneuropathies of other origin. The occurrence of these disorders does not exclude the possibility of a simultaneous occurrence of the hand-arm vibration syndrome. If a polyneuropathy is dominant in the upper extremities, the diagnosis of the syndrome is more obvious.

\section{References}

1. Dawson DM, Hallet M, Millender LH. Entrapment neuropathies. Little, Brown and Company, Boston/Toronto 1983.

2. Dyck PJ, Thomas PK, Lambert EH, Bunge R. Peripheral neuropathy. WB Saunders, Philadelphia, PA 1984.

3. Färkkilä M, Aatola S, Starck J, Pyykkö I, Korhonen $\mathrm{O}$. Vibration-induced neuropathy among forestry workers. Acta Neurol Scand 71 (1985) 221-225. 
4. Gemne G, Taylor W, ed. Hand-arm vibration and the central autonomic nervous system. J Low Freq Noise Vib 1 (1983): special issue.

5. Härkönen H, Riihimäki H, Tola S, Mattson T, Pekkarinen $\mathrm{M}$, Zitting $\mathrm{A}$, Husman $\mathrm{K}$. Symptoms of vibration syndrome and radiographic findings in the wrist of lumberjacks. Br J Ind Med 41 (1984) 133-136.

6. Juntunen J. Alcoholic polyneuropathy. Acta Med Scand Suppl 703 (1985) 265-272.

7. Juntunen J, Haltia M. Polyneuropathies in occupational neurology: Pathogenetic and clinical aspects. Acta Neurol Scand 66 (1982) 59-73.

8. Juntunen J, Matikainen E, Seppäläinen AM, Laine A. Peripheral neuropathy and vibration syndrome: A clinical and neurophysiological study of 103 patients. Int Arch Occup Environ Health 52 (1983) 17-24.

9. Lukáš E. Lesion of the peripheral nervous system due to vibration. Work Environ Health 7 (1970) 67-79.

10. Pyykkö I. The hand-arm vibration syndrome: Defini- tions and assessment of symptoms. J Low Freq Sound Vib 1 (1983): special issue, 6-18.

11. Pyykkö I, Korhonen O, Färkkilä M, Starck J, Aatola $\mathrm{S}$. A longitudinal study of the vibration syndrome in Finnish forestry workers. In: Brammer A, Taylor W, ed. Vibration effects on the hand-arm in industry. John Wiley \& Sons, New York NY 1982.

12. Pyykkö I, Sairanen E, Korhonen O, Färkkilä M, Hyvärinen $\mathrm{J}$. A decrease in the prevalence and severity of vibration-induced white fingers among lumberjacks in Finland. Scand J Work Environ Health 4 (1978) 246254.

13. Starck J. High impulse acceleration levels in hand-held vibratory tools: An additional factor in the hazards associated with the hand-arm vibration syndrome. Scand J Work Environ Health 10 (1984) 171-178.

14. Starck J, Färkkilä M, Aatola S, Korhonen O. Vibration syndrome and vibration in pedestal grinding. $\mathrm{Br} \mathrm{J}$ Ind Med 40 (1983) 426-433. 